\title{
Typology of Peri-Urban Area Based on Physical and Social Aspects in Marisa, Indonesia
}

\author{
Irwan Wunarlan $^{1,2, *}$, Sugiono Soetomo ${ }^{3}$, Iwan Rudiarto ${ }^{4}$ \\ ${ }^{1}$ Doctoral Candidate of Architecture and Urban Engineering, Universitas Diponegoro, Semarang, Indonesia \\ ${ }^{2}$ Lecturer of Architecture, Faculty of Engineering, Universitas Negeri Gorontalo, Indonesia \\ ${ }^{3}$ Lecturer at Postgraduate Program of Architecture and Urban Engineering, Universitas Negeri Gorontalo, Indonesia \\ ${ }^{4}$ Lecturer at Postgraduate Program of Urban and Regional Planning, Universitas Diponegoro, Semarang, Indonesia
}

Received July 3, 2020; Revised September 13, 2020; Accepted October 19, 2020

\section{Cite This Paper in the following Citation Styles}

(a): [1] Irwan Wunarlan, Sugiono Soetomo, Iwan Rudiarto , "Typology of Peri-Urban Area Based on Physical and Social Aspects in Marisa, Indonesia," Civil Engineering and Architecture, Vol. 8, No. 5, pp. 984 - 992, 2020. DOI: 10.13189/cea.2020.080525.

(b): Irwan Wunarlan, Sugiono Soetomo, Iwan Rudiarto (2020). Typology of Peri-Urban Area Based on Physical and Social Aspects in Marisa, Indonesia. Civil Engineering and Architecture, 8(5), 984 - 992. DOI: 10.13189/сеа.2020.080525.

Copyright $\bigcirc 2020$ by authors, all rights reserved. Authors agree that this article remains permanently open access under the terms of the Creative Commons Attribution License 4.0 International License

\begin{abstract}
Peri-urban is commonly defined as an area around the sub-urban region that has the hybrid characteristics between an urban area and a rural area. The study aimed to investigate the change of regional typology due to the progress of the peri-urban area in Marisa based on the physical and social aspects in 1980 and in 2017. Encompassing two districts, the study employed descriptive-quantitative method and analysis techniques, i.e., overlay, scoring, and spatial. The results showed that in 1980, four districts were included in the rural frame zone (zona bidang desa) category. Moreover, seven sub-districts were categorized as rural-urban frame zone (zona bidang desa kota) while the rest were included in the rural frame zone category. In 2017, a change of typology from rural-urban frame zone to urban-rural frame zone occurred in several villages/sub-districts, i.e., Libuo, South Marisa, North Marisa, and Pohuwato. Over a span of 37 years, the typology of several sub-districts has changed from rural frame zone to urban frame zone in Libuo, South Marisa, North Marisa, and Pohuwato village/sub-district. The urban sprawl in areas in Marisa has increased the need for an integrated policy to create a balanced spatial development.
\end{abstract}

Keywords Peri-Urban Area, Spatial, Village/ Sub-district, City, Marisa

\section{Introduction}

Population growth in urban areas has instigated the need for availability of land in the area; such a phenomenon has changed the land function from non-developed to developed (Miljkovic, Tijana \& Igor, 2012). The land condition in urban areas, however, has limited capacity. As a result, regions that share their borders with an urban area are more likely to follow the urban area's sprawl. Such regions that are influenced by an urban area's development is defined as peri-urban. A peri-urban is an area that experiences change and adopts urban characteristics; therefore, a peri-urban is the multifunctional transition zone between a city and a village/sub-urban. In addition, the area is commonly interpreted as an area in the sub-urban region that has hybrid characteristics between an urban area and a rural area (Salem, Naoki, and Prasanna, 2019). Such hybrid characteristics are apparent in the pattern of land use, demographic characteristics, and public service/infrastructure (Rudiarto, et al., 2013). Moreover, Peri-urban is said to progress in three aspects: physical aspect (land use, infrastructure), social aspect (population density and ratio, low mortality rate, human resources rate, heterogeneity, etc.), and economic aspect (livelihood, pre-welfare proportion, etc.) (Reny; 2014; Budiyantini et al., 2016).

Marisa is the capital of Pohuwato Regency, Gorontalo Province. It is located quite far from the province capital of 
Gorontalo city (158 km). Due to the far distance, it receives very little influence from the province capital. With a surplus of commodities from the agriculture, plantation, and fishery sectors, Marisa has developed into an urban region with rural characteristics. The region is located at the main section of Trans Sulawesi roads that connects two of the nationally-active regions, viz. Gorontalo and Palu. A region/city located on the main road and has surplus agricultural commodities is more likely to develop (Tacoli, 2003; Tacoli, 2004). The region is one of the regency's main governmental sectors, particularly in Palopo sub-district. The governmental sector that was once located at South Marisa village has instigated an urban sprawl phenomenon to other districts; this, in turn, impacts the region's physical features. The change of land use that occurs in Marisa district will be impactful towards the typology and overall development process of the region. Such a phenomenon requires a well-implemented urban area planning policy. The study aimed to identify the distribution of peri-urban area in Marisa that impacts the regional development and the progress of the region's peri-urban typology from 1980 to 2017. The information acquired is expected to be beneficial for the local stakeholders as a reference in conducting well-planned development policies in the future. The peri-urban analysis focuses on the physical (land use) and social (population density, livelihood) aspects of the region.

\section{Research Method}

The research was conducted in 11 villages/sub-districts in Marisa district. The region is $5986.59 \mathrm{Ha}^{2}$ in size; the region's center is located in North Marisa sub-district. The research relied on primary and secondary data obtained from the Statistical Bureau of Pohuwato regency, i.e., total land use for agriculture, livelihood, and population density. The study employed a descriptive-quantitative method as well as an overlay, scoring, classification, and spatial analysis techniques. Overlay analysis was conducted to compile the secondary data that consisted of population density, developed land, livelihood, and area of agricultural land. Moreover, scoring and classification analysis was conducted to classify the region into four typology zones: urban frame zone (zobikot), urban-rural frame zone (zobikodes), rural-urban frame zone (zobidekot), and rural frame zone (zobides) (Yunus, 2008). On top of that, the spatial analysis was involved in identifying the distribution of the peri-urban typology in Marisa, 1980-2017.

Several factors are said to contribute to the classification of a region's urban characteristics: population density (Rudiarto et al., 2013), accessibility and public facility (Budiyantini and Pratiwi, 2016), physical aspect (land use and area of developed land), and social aspect (population density and livelihood) (Yunus, 2008).

Based on the notions above, the typology classification (Yunus, 2008) of Marisa district referred to the physical aspects (land use and developed land area) and socioeconomic aspects (population density and livelihood). The typology was classified into four zones: urban frame zone (zobikot), urban-rural frame zone (zobikodes), rural-urban frame zone (zobidekot), and rural frame zone (zobides). The data of the percentage of land use, developed land, population density, and livelihood are presented in the following Table 1.

Following the scoring process, the next step was to calculate the typology of each region from the value acquired in the previous process. The region classification (or zoning) referred to the accumulation and range of scores obtained from the data. For instance, the urban frame zone typology has 20-18 value, in which 20 is the upper limit value, and 18 is the lower limit value. The lower limit value of urban frame zone typology is one value higher than the upper limit value of the urban-rural frame zone. Such an analogy became the reference for the determination of area zoning in the region. Moreover, the urban-rural frame zone has 15-10 value, while the rural-urban and urban frame zones have $10-5$ and $\leq 5$ value in respective order.

The classification process of Marisa district was observed from the region's physical and social aspects. Therefore, the classification process applied the primary and secondary data; following that, the processed data were further classified into the region zoning criteria of Marisa district.

Table 1. Area Zoning Criteria

\begin{tabular}{|c|c|c|c|c|}
\hline \multirow{2}{*}{ Activity } & \multicolumn{4}{|c|}{ Spatial/Area Zone } \\
\cline { 2 - 5 } & $\begin{array}{c}\text { Urban Frame Zone } \\
\text { (Score 4) }\end{array}$ & $\begin{array}{c}\text { Urban-rural Frame Zone } \\
\text { (Score 3) }\end{array}$ & $\begin{array}{c}\text { Rural-urban Frame Zone } \\
\text { (Score 2) }\end{array}$ & $\begin{array}{c}\text { Rural Frame Zone } \\
\text { (Score 1) }\end{array}$ \\
\hline Agriculture & $<25 \%$ & $>25 \%-<50 \%$ & $>50 \%-<75 \%$ & $>75 \%$ \\
\hline Non-agriculture & $>75 \%$ & $>50 \%-<75 \%$ & $>25 \%-<50 \%$ & $<25 \%$ \\
\hline Developed land & $>75 \%$ & $>50 \%-<75 \%$ & $<25 \%-<50 \%$ & $<25 \%$ \\
\hline Population Density & $\geq 5.000$ people/km2 & $\geq 3.000-<5.000$ people/km2 & $\geq 1.000-<3.000$ people/km2 & $<1.000$ people/km2 \\
\hline Agricultural livelihood & $<25 \%$ & $>25 \%-<50 \%$ & $>50 \%-<75 \%$ & $>75 \%$ \\
\hline Total score & 20 & 15 & 10 & 5 \\
\hline
\end{tabular}

Source: Yunus, 2008; Rudiarto, et al, 2013; Muta’ali, 2015; Budiyantini \& Pratiwi, 2016 


\section{Findings and Discussion}

The classification process of peri-urban typology in Marisa district refers to the region's physical and social aspects. The result of the comparison between primary and secondary data based on the criteria from Table 1 is as follows:

\section{Physical Aspect}

In the physical aspect, the classification of peri-urban typology is conducted by determining the percentage of the area between agricultural land and land for non-agricultural uses. In particular, the classification observes on the percentage of the area of land use as well as developed land. The percentage is displayed in the following Table 2.

Table 2 below indicates that the village/sub-district with the highest and the lowest percentage of agricultural land in 1980 was Buhu Jaya (93.10\%) and Maleo (28.68\%), respectively. In 2000, Buhu Jaya (94.14\%) remained in the region with the highest percentage of agricultural land, while Libuo (38.17\%) sat at the lowest percentage. Further, in 2017, Buhu Jaya (99.76\%) still remained at the top of the table of percentage of agricultural land, while East Pohuwato (26.93\%) became the region with the lowest agricultural land percentage. It indicates that the villages/sub-districts in Marisa region are rural settlement areas. The distance between houses is quite far; houses are separated from lands, coconut plantations, or maize farms.

The composition of land use for agriculture is said to be one of the criteria in determining the typology of a region. Such criteria are presented in appendix 9. Employing the criteria in Table 1, the classification result of Marisa district is as follows:

1. In 1980, four villages/sub-districts were classified into the urban-rural frame zone, i.e., Maleo, Libuo, Pohuwato, and Teratai. On top of that, Bulangita was the only region that fell into the rural-urban frame zone. Simultaneously, the other six villages/sub-districts (Buhu Jaya, Botubilotahu Indah, South Marisa, North Marisa, Palopo, and East Pohuwato) were classified into rural frame zone.

2. In 2000, Libuo and Pohuwato were classified into urban-rural frame zone, while Maleo, South Marisa, and Teratai fell into the rural-urban frame zone. Besides, six other regions (Buhu Jaya, Botubilotahu Indah, Bulangita, North Marisa, Palopo, and East Pohuwato) were classified into rural frame zone.

3. Further, in 2017, Libuo, Pohuwato, and East Pohuwato were classified into urban-rural frame zone, while the other six regions (Maleo, Bulangita, South Marisa, North Marisa, Palopo, and Teratai) fell into the rural-urban frame zone. Also, Buhu Jaya, Bulangita, and Botubilotahu Indah were classified into rural frame zone. Based on the elaboration above, the villages/sub-districts that experienced a change of typology are Maleo (from urban-rural frame zone in 1980 to rural-urban frame zone in 2017); North Marisa, South Marisa, and Palopo (from rural frame zone in 1980 to rural-urban frame zone in 2017); East Pohuwato (from rural frame zone in 1980 to urban-rural frame zone in 2017); and Teratai (from urban-rural frame zone in 1980 to rural-urban frame zone in 2017).

Table 2. Percentage of Area of Land Use in Marisa City from 1980-2017

\begin{tabular}{|c|c|c|c|c|c|c|c|}
\hline \multirow{2}{*}{ No } & \multirow{2}{*}{ Village/Sub-district } & \multicolumn{3}{|c|}{ Agriculture (\%) } & \multicolumn{3}{c|}{ Non-agriculture (\%) } \\
\cline { 2 - 8 } & & 1980 & 2000 & 2017 & 1980 & 2000 & 2017 \\
\hline 1 & Buhu Jaya & 93.10 & 94.14 & 82.80 & 6.90 & 5.86 & 17.20 \\
\hline 2 & Libuo & 30.60 & 38.17 & 34.52 & 69.40 & 61.83 & 65.48 \\
\hline 3 & Maleo & 28.68 & 71.28 & 66.19 & 71.32 & 28.72 & 33.81 \\
\hline 4 & Botubilotahu Indah & 78.52 & 81.65 & 71.10 & 21.48 & 18.35 & 28.90 \\
\hline 5 & Bulangita & 61.13 & 87.62 & 99.76 & 38.87 & 12.38 & 0.24 \\
\hline 6 & South Marisa & 82.36 & 74.85 & 57.29 & 17.64 & 25.15 & 42.71 \\
\hline 7 & North Marisa & 85.03 & 78.38 & 50.66 & 14.97 & 21.62 & 49.34 \\
\hline 8 & Palopo & 82.37 & 80.45 & 65.17 & 17.63 & 19.55 & 34.83 \\
\hline 9 & Pohuwato & 68.99 & 48.35 & 43.57 & 31.01 & 51.65 & 56.43 \\
\hline 10 & East Pohuwato & 90.33 & 86.72 & 26.93 & 9.67 & 13.28 & 73.07 \\
\hline 11 & Teratai & 39.30 & 70.09 & 62.81 & 60.70 & 29.91 & 37.19 \\
\hline
\end{tabular}

Source: Base map of 1980-2017 


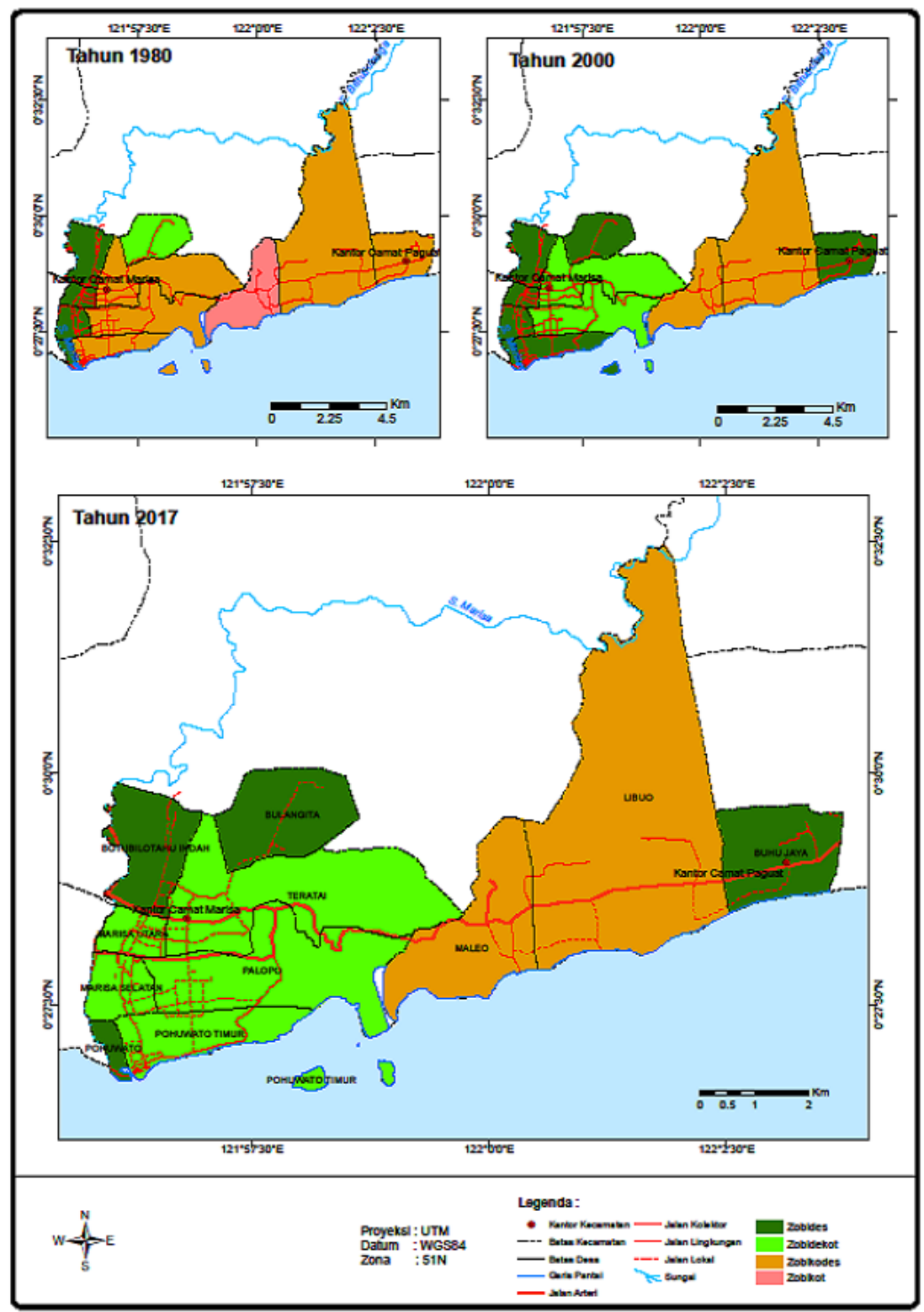

Figure 1. Typology of the urban area in Marisa based on agricultural land use

The analysis of the composition of land use for agriculture in Marisa generates spatial classification regarding the typology of the region, as presented in Figure 1 above.

Moreover, the analysis observes the second physical aspect, i.e., use of developed and to classify the typology of Marisa region over the span of 37 years. The percentage of use of developed land is shown in the following table.

The criteria of use of developed land, as shown in Table 3 , is treated as the reference in determining the region's typology. The typology of each village/sub-district in
Marisa from 1980 to 2017 based on the use of developed land is as follows:

1. In 1980 and 2000, all eleven villages/sub-districts in Marisa and Paguat districts were classified into the rural frame zone.

2. Further, in 2017, two villages/sub-districts (North Marisa and South Marisa) have changed into rural-urban frame zone, while the rest remained in rural frame zone typology South Marisa and North Marisa were the only regions that progressed from rural frame zone to rural-urban frame zone. 
Table 3. Percentage of Area of Developed Land in Urban Areas in Marisa from 1980-2017

\begin{tabular}{|c|c|c|c|c|}
\hline \multirow{2}{*}{ No } & \multirow{2}{*}{ Village/Sub-district } & \multicolumn{3}{|c|}{ Developed land (\%) } \\
\cline { 3 - 5 } & & 1980 & 2000 & 2017 \\
\hline 1 & Buhu Jaya & 5.86 & 5.86 & 7.50 \\
\hline 2 & Libuo & 1.18 & 1.31 & 2.25 \\
\hline 3 & Maleo & 2.87 & 5.03 & 9.41 \\
\hline 4 & Botubilotahu Indah & 4.66 & 8.70 & 19.14 \\
\hline 5 & Bulangita & 0.00 & 2.33 & 2.73 \\
\hline 6 & South Marisa & 8.82 & 13.18 & 38.16 \\
\hline 7 & North Marisa & 11.63 & 15.82 & 43.99 \\
\hline 8 & Palopo & 0.06 & 2.91 & 13.79 \\
\hline 9 & Pohuwato & 4.98 & 30.73 & 81.63 \\
\hline 10 & East Pohuwato & 2.70 & 8.08 & 25.56 \\
\hline 11 & Teratai & 0.00 & 1.14 & 8.72 \\
\hline
\end{tabular}

Source: Base map of 1980-2017

The above table displays that Pohuwato underwent relatively rapid development, with a high percentage of developed land area (81.63 percent as per 2017). Since the sub-district has an area of 78.65 hectares, the region is considered to have high settlement density, in which the distance between houses is one meter or less. The regions are also considered as the supporting area of Marisa due to its function as the central business district. In 2017, the regions in second and third rank were North Marisa and South Marisa, with a percentage of the developed land area of 43.99 percent and 38.16 percent, respectively. Both sub-districts are the central region of Marisa since all the infrastructure and public utilities that serve the community of Marisa region are built in these locations.

Meanwhile, in the same year, Libuo was the region with the lowest percentage of the developed land area since the region has the largest area of 1,975.85 hectares with a relatively small population (1,473 people). Libuo is industrial development in Pohuwato regency; facilities of maize and coconut food product processing are built within the region. Moreover, Libuo is located nearby the Panua natural reserve. Therefore, the build-up area in the location is restricted.

The typology shift that occurred in villages/sub-districts in Marisa is caused by housing/settlements building construction, migration, and availability of public infrastructure. The spatial typology is illustrated in Figure 2.

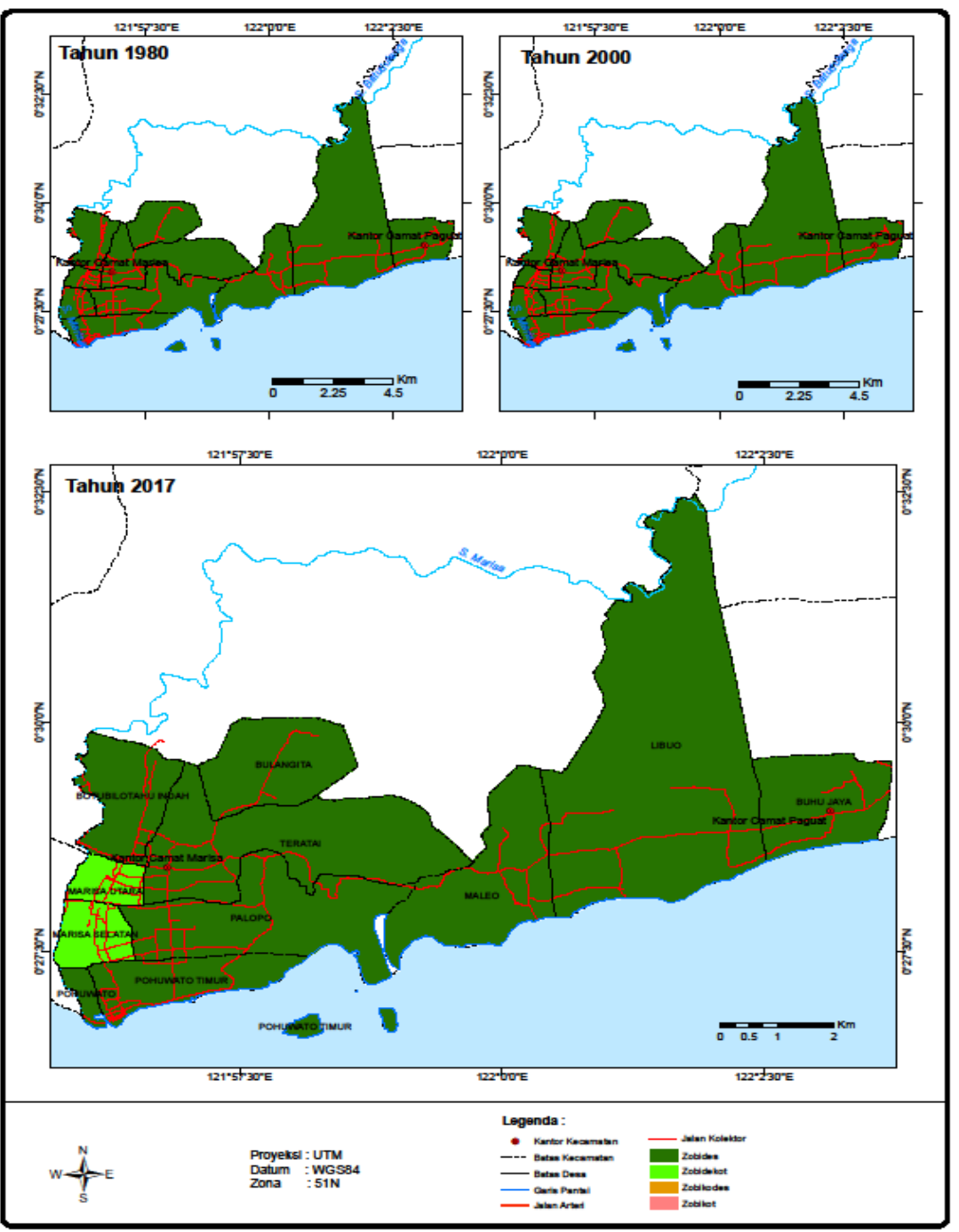

Figure 2. Typology of Urban Area in Marisa based on Developed Land 


\section{Analysis of Social Aspects in Marisa}

Table 4. Urban Population Capacity in Marisa from 1980-2017

\begin{tabular}{|c|c|c|c|c|}
\hline \multirow{2}{*}{ No } & \multirow{2}{*}{ Village/Sub-district } & \multicolumn{3}{|c|}{ Population Density (people $/ \mathrm{km}^{2}$ ) } \\
\hline & & 1980 & 2000 & 2017 \\
\hline 1 & Buhu Jaya & 142 & 133 & 127 \\
\hline 2 & Libuo & 17 & 24 & 29 \\
\hline 3 & Maleo & 26 & 37 & 47 \\
\hline 4 & Palopo & 5 & 57 & 161 \\
\hline 5 & Teratai & 127 & 269 & 390 \\
\hline 6 & Bulangita & 4 & 27 & 161 \\
\hline 7 & South Marisa & 1615 & 1107 & 674 \\
\hline 8 & North Marisa & 1629 & 2074 & 2453 \\
\hline 9 & Botubilotahu Indah & 438 & 848 & 1196 \\
\hline 10 & Pohuwato & 1745 & 2560 & 3252 \\
\hline 11 & East Pohuwato & 142 & 208 & 264 \\
\hline \multicolumn{2}{|r|}{ Average Density } & 535.47 & 667.55 & 795.80 \\
\hline
\end{tabular}

Source: Statistical Bureau of Pohuwato Regency (processed)

In the social aspect, the regional zoning refers to the indicators of population density and livelihood. Data on population density is acquired from the total population in each village/sub-district per region area; meanwhile, data of livelihood is obtained from the percentage of the community's livelihood in the region. Table 4 shows the population density of Marisa from 1980 to 2017. The table also informs that in 2017, Pohuwato district was the most population-dense region of Marisa due to its function as the embryo of Marisa region. It also acts as the destination area for new settlers looking for better livelihood in the region. The second and third-most dense regions are North Marisa and South Marisa; the regions are the central business district of Marisa area.

As presented in the previous Table 4, the population density in Marisa over the span of 37 years is elaborated as follows: From 1980 to 2017, Pohuwato was the region with the highest population density $\left(3,252\right.$ people $\left./ \mathrm{km}^{2}\right)$; the region is mostly known of its fisheries commodity. Meanwhile, Libuo, as the region with a vast plantation area, was at the bottom with the lowest density (29 people $/ \mathrm{km}^{2}$ ); the region is well-known to have coconut and maize plantations

The typology of regions in Marisa based on population density is as follows:

1. In 1980, three villages/sub-districts were classified into rural-urban frame zone, while the rest eight regions fell into rural frame zone (see appendix).

2. Further, from 2000-2017, the typology in Marisa did not see significant changes, except South Marisa and Botubilotahu Indah. South Marisa changed from the rural-urban frame zone in 2000 to a rural frame zone in 2017. In the meantime, Botubilotahu Indah progressed from the rural frame zone in 2000 to the rural-urban frame zone in 2017.

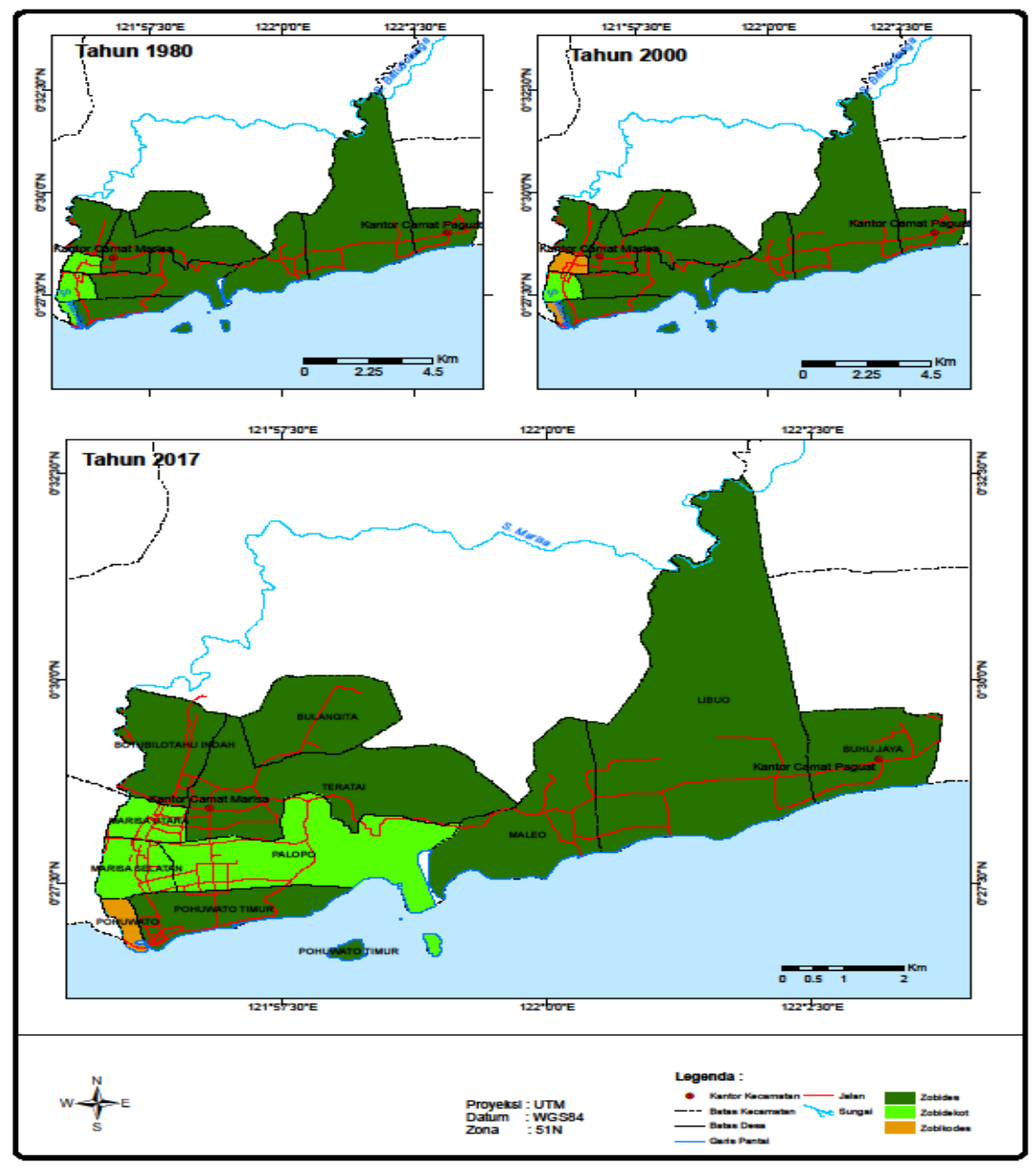

Figure 3. Typology of Urban Area in Marisa Based on Population Density 
Table 5. Percentage of Livelihood in Marisa City from 1980-2017.

\begin{tabular}{|c|c|c|c|c|}
\hline \multirow{2}{*}{ No } & \multirow{2}{*}{ Village/Sub-district } & \multicolumn{3}{|c|}{ Agricultural sector (\%) } \\
\cline { 3 - 5 } & & 1980 & 2000 & 2017 \\
\hline 1 & Buhu Jaya & 83.72 & 80.29 & 75.72 \\
\hline 2 & Libuo & 73.58 & 71.20 & 69.17 \\
\hline 3 & Maleo & 76.65 & 72.33 & 73.23 \\
\hline 4 & Botubilotahu Indah & 77.07 & 75.08 & 72.65 \\
\hline 5 & Bulangita & 79.83 & 76.16 & 71.22 \\
\hline 6 & South Marisa & 74.11 & 70.01 & 68.44 \\
\hline 7 & North Marisa & 71.31 & 69.41 & 71.72 \\
\hline 8 & Palopo & 82.26 & 72.24 & 71.69 \\
\hline 9 & Pohuwato & 79.23 & 73.32 & 69.87 \\
\hline 10 & East Pohuwato & 81.04 & 75.08 & 73.01 \\
\hline 11 & Teratai & 82.71 & 76.05 & 64.17 \\
\hline
\end{tabular}

Source: Statistical Bureau of Pohuwato Regency and National Socioeconomic Survey Data (processed)

Further, Table 5 displays information on the community's livelihood in Marisa. Agriculture is among the community's main livelihood in the region. In 1980, Buhu Jaya (83.72\%), Palopo (82.26\%), and Teratai $(83.72 \%)$ had the highest rate of people working in the agriculture sector. The regions are composed mostly of agriculture areas, while most of the community members are farmers with quite large farmland. Meanwhile, North Marisa (71.31\%) was the region with the lowest percentage of livelihood in the agriculture sector. The regions are mainly composed of businesses, the industrial sector, and public infrastructures. Therefore, the agricultural lands in the regions are limited.

From the period of 1980, 2000, to 2017, Buhu Jaya was the region with the highest rate of people working in the agriculture sector, with a percentage of $83.72 \%, 80.29 \%$, and $75.72 \%$ in respective order. Buhu Jaya is considered a suburban area that has a huge portion of land for agriculture. In the same time frame, South Marisa was the region with the lowest rate of livelihood in the agriculture sector, with a percentage measuring at $74.11 \%, 70.01 \%$, and $68.44 \%$, respectively. The regions are located in the central business area and have limited agricultural land, similar to the North Marisa sub-district.

Based on the livelihood, the typology in 1980 illustrates that only Libuo, South Marisa, and North Marisa were classified into rural-urban frame zone while the rest was classified into a rural frame zone. In 2000, six villages/sub-districts were classified into rural-urban frame zones. The rest five regions fell into the rural frame zone typology. In 2017, ten villages/sub-districts were classified into rural-urban frame zones. The rest one region fell into the rural frame zone typology.

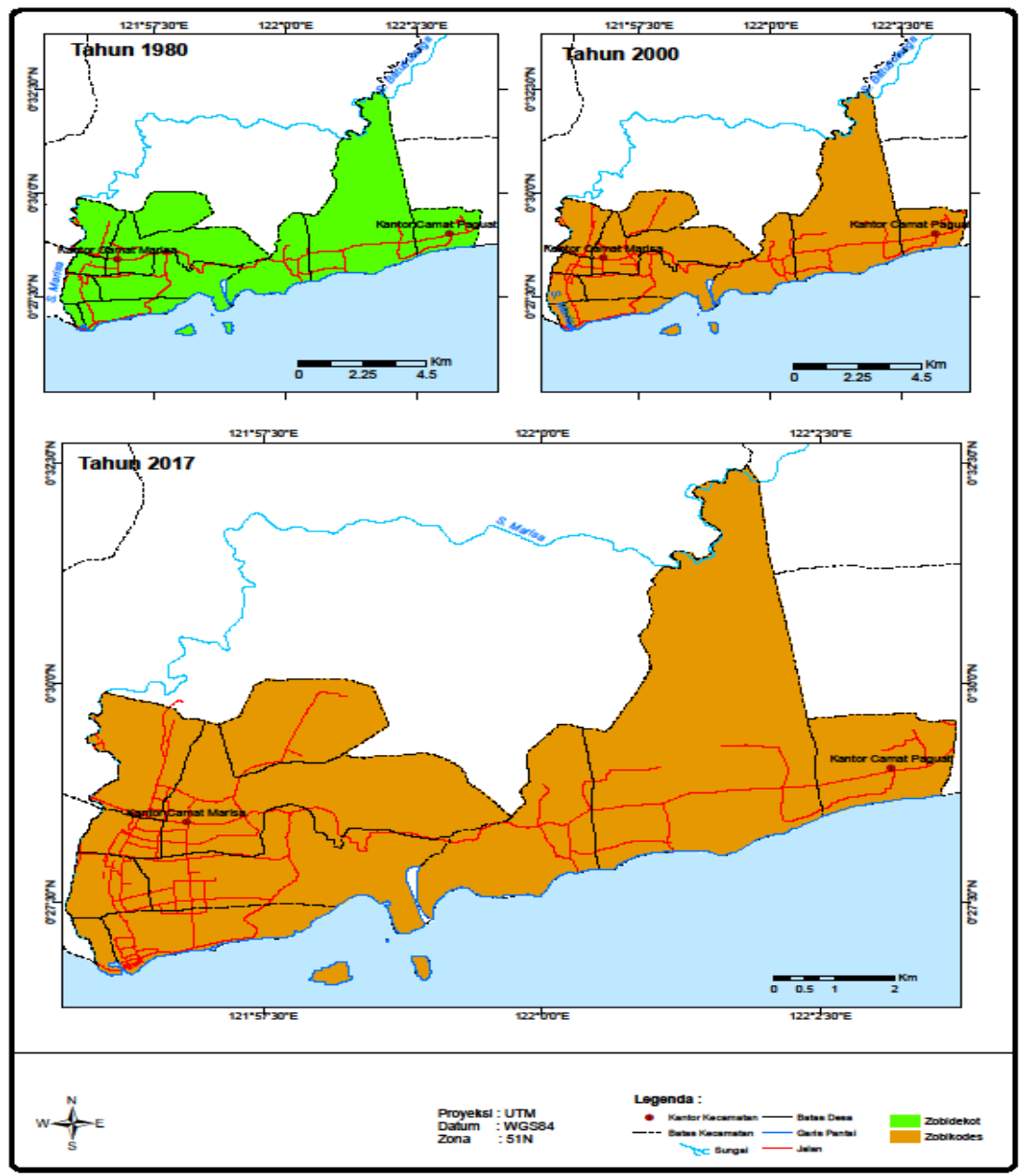

Figure 4. Typology of Marisa from 1980-2017 based on livelihood in the agriculture sector. 


\section{Analysis of Social and Physical Typology of Marisa City}

The classification of typology in Marisa region employs map overlay and scoring methods. The typology is illustrated in Figure 5.

Based on Figure 5 above, in 1980, four regions (Buhu Jaya, Botubilotahu Indah, Palopo, and East Pohuwato) were classified into rural frame zone, while other regions fell into the rural-urban frame zone. In 2000, Libuo, Maleo, South Marisa, North Marisa, Pohuwato, and Teratai were classified into rural-urban frame zone. Further, three villages were classified into rural-urban frame zone in 2017, i.e., South Marisa, North Marisa, and Pohuwato. Over 37 years, it is apparent that the change of typology occurs in several regions. Regions that were once classified as rural frame zone changed into rural-urban frame zone, while regions that were once classified into rural-urban frame zone progressed into the urban-rural frame zone. The detailed elaboration of typology change in regions in Marisa is described as follows:

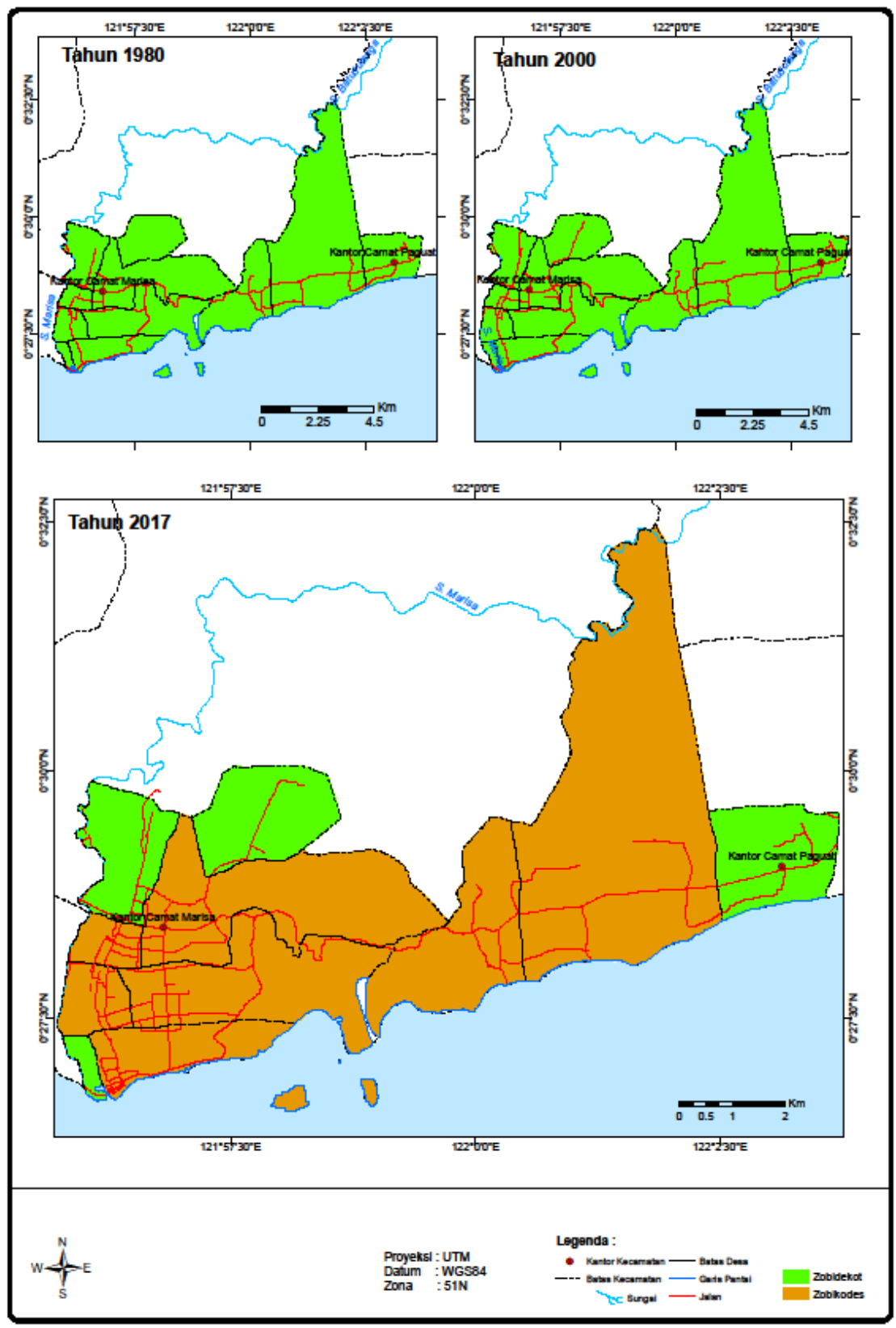

Figure 5. Regional typology of Marisa district from 1980-2017 based on physical and social aspects. 
1. In 1980, four regions were included in the rural frame typology, i.e., Buhu Jaya, Botubilotahu Indah, Palopo, and East Pohuwato, while the other regions were classified as rural-urban frame zone (Libuo, Maleo, Teratai, Bulangita, North Marisa, South Marisa, and Pohuwato).

2. In 2000, the typology remained in the same zone.

3. Further, in 2017, Buhu Jaya remained in the same typology, while Libuo, South Marisa, North Marisa, and Pohuwato progressed from rural-urban frame zone to urban-rural frame zone. Moreover, six of eleven regions (Botubilotahu Indah, Bulangita, Palopo, and East Pohuwato) experienced a change of typology.

Figure 5 describes the typology of Marisa region for the period of 1980, 2000, and 2017.

The various typology change in the region is caused by several factors: (1) limited budget of physical construction that forces the government to focus on the construction of governmental offices or public service buildings; (2) the economic activity that relies highly on the primary agricultural activities, providing minimal contribution or multiplier effect towards the community's welfare state and regional development; (3) lack of synergy in urban planning policies; and (4) very wide range of development control that makes it hard for the development plan to reach hinterland regions.

\section{Conclusion}

Central to a city's urban development is the region's physical and social aspects. In line with this, Marisa has experienced quite a progress regarding urban development in the region. Based on the physical and social aspects, in 1980, four villages/sub-districts were classified into rural frame zone, i.e., Buhu Jaya, Botubilotahu Indah, Palopo, and East Pohuwato, while the rest were included in rural-urban frame zone. On top of that, in 2000, all regions in Marisa fell into rural frame zone typology. Over 37 years, the typology of several villages (Libuo, South Marisa, North Marisa, and Pohuwato village/sub-district) has changed from the rural-urban frame zone to urban-rural frame zone. The classification of peri-urban typology elaborates on the range of influence of urban activity from North Marisa sub-district to the outermost part of Marisa, i.e., Buhu Jaya and Bulangita.
On top of that, the urban sprawl is observed to spread gradually to the outside of Marisa region, i.e., in Duhiadaa and Buntulia districts. Therefore, the government of Pohuwato regency is required to formulate spatial planning policies regarding the impact of urban sprawl on other districts. Such conducts function to control the land use in the region and to maintain the regional development to comply with the regional objectives.

\section{REFERENCES}

[1] Allen, A., 2003. Environmental Planning and Management of the Peri-Urban Interface: Perspectives on an Emerging Field. Environ. Urban., 15, 135-148.

[2] BPS., 2016. Kecamatan Marisa Dalam Angka [Marisa District in Numbers]. BPS Kab. Pohuwato.

[3] BPS., 2016. Kecamatan Paguat Dalam Angka [Paguat District in Numbers]. BPS Kab. Pohuwato.

[4] Budiyantini, Y and Pratiwi, V., 2016. Peri-urban typology of Bandung Metropolitan Area. Procedia: Social and Behavior Science. Science Direct. pp: 833-837.

[5] Miljkovic, J.Z., Tijana, C and Igor, M., 2012. Land use Planning for Sustainable Development of Peri Urban Zones. Spatium International Review, No. 2. pp: 15-22.

[6] Nela.A.K (2013). Klasifikasi Tipologi Zona Perwilayahan Wilayah Peri-Urban di Kecamatan Kartasura [Classification of Peri-urban Typology in Kartasura District]. Jurnal Wilayah dan Lingkungan, 1(3) 251-264.

[7] Reny Yesiana (2014). Typologies of Peri-Urban Klaten-Central Java: Based on Socio-Economic Perspective. The Indonesian Journal of Planning and Development, 1(1), 57-64

[8] Rudiarto. I, Handayani. W, Pigawati. B dan Pangi (2013). Zona Peri Urban Semarang Metropolitan:Perkembangan dan Tipologi Sosial Ekonomi []. Jurnal Tata Loka, 15(2), $116-128$

[9] Salem, M., Naoki, T., Prasanna, D., 2019. Analyzing the Driving Factors Causing Urban Expansion in the Peri-Urban Areas Using Logistic Regression: A Case Study of the Greater Cairo Region. Infrastructures, 4(4). pp: 1-14.

[10] Yunus, H. Sabari., 2008. Dinamika Wilayah Peri Urban: Determinan Masa Depan Wilayah Kota. Yogyakarta. Pustaka Pelajar. 